\title{
NAPELEM MÚLTJA, JELENE ÉS JÖVŐJE
}

\author{
Tóth Anett \\ hallgató, Miskolci Egyetem, Energetikai és Vegyipari Gépészeti Intézet, \\ Aramlás és Hötechnikai Gépek Intézeti Tanszék \\ 3515 Miskolc, Miskolc-Egyetemváros, e-mail: anett.toth0123@gmail.com
}

\author{
Voith Katalin \\ tudományos fömunkatárs, Miskolci Egyetem, Energetikai és Vegyipari Gépészeti Intézet, \\ Aramlás és Hötechnikai Gépek Intézeti Tanszék \\ 3515 Miskolc, Miskolc-Egyetemváros, e-mail: gkdh12@uni-miskolc.hu
}

\begin{abstract}
Absztrakt
Évekkel ezelött luxuscikknek mondható volt a napelem, de ma már lassan hétköznapi elemmé válik. Érdekes és hasznos ez a témakör, hiszen kis befektetéssel akár hosszú éveken át megkönnyitheti a mindennapokat a magánszemély, de a nagy befektetök számára is. Számos pozitiv tulajdonsággal rendelkezik a napelem: óvja, védi a környezetünket, mert nincs széndioxid és egyéb környezetszennyezö gáz kibocsátás, illetve olyan helyeken is lehetöség van az áram biztositására, ahol nincs kiépitett villamoshálózat. A napelemekkel termelt áram akkumulátorokban eltárolható. Az alábbi cikkben a napelemek múltját, jelenét, illetve jövöjét és azzal kapcsolatos kutatásokat foglaljuk össze.
\end{abstract}

Kulcsszavak: napelem, STCS, PV-SWHS, perovszkit kristály

\begin{abstract}
Many years ago, a solar panel was a luxury item, but it is slowly becoming an everyday item. This is an interesting and useful topic, since with a small investment it can make everyday life easier for many years, for a private person and even for large investors. The solar panel has many positive features such as it protects our environment by avoiding the release of carbon dioxide and other polluting gases and provide power in places where there is no network of electricity. Further advantage of the solar panel that the solar power can be stored in batteries. In the following article, the past, present and future of solar panels and related research works will be examined.
\end{abstract}

Keywords: Solar panel, Solar Thermal Collector System (STCS), Photovoltaic Solar Water Heater System (PV-SWHS), Perovskite

\section{Bevezetés}

A nap a Naprendszerben a legnagyobb energiaforrás, ami azt jelenti, hogy a mindennapi életünkben felhasznált energia közvetlenül vagy közvetve, de a napsugárzásával köthetö össze [10]. A Földön minden élőlény, még az óceán legsötétebb részein is, a mikrobák élete is függ a Naptól [2].

A nap által lett élet a Földön, és életünket elképzelni nem lehet nélküle. A napfény energiáját már az ösi civilizációkban is hasznosították. Azóta már ezen a területen számos innovatív technológia változás és fejlesztés került sorra. Az emberek energiaigénye ősidők óta fennáll, és folyamatosan növekedik [1]. 


\section{A napelem felhasználás múltja}

A nap létfontosságú szerepet játszik a földi életben. Ezt az ősi kultúrák már elismerték és ünnepelték. Ezen idők emberei csodálták a Napot, gyakran megszemélyesítették és istenként imádták. Aten volt a napfény az egyiptomi mitológiában, és eredetileg Ra isten az egyiptomiak napistene. Atennel a napfényen keresztül lehetett kapcsolatba lépni ahogy az 1. ábra mutatja [1].

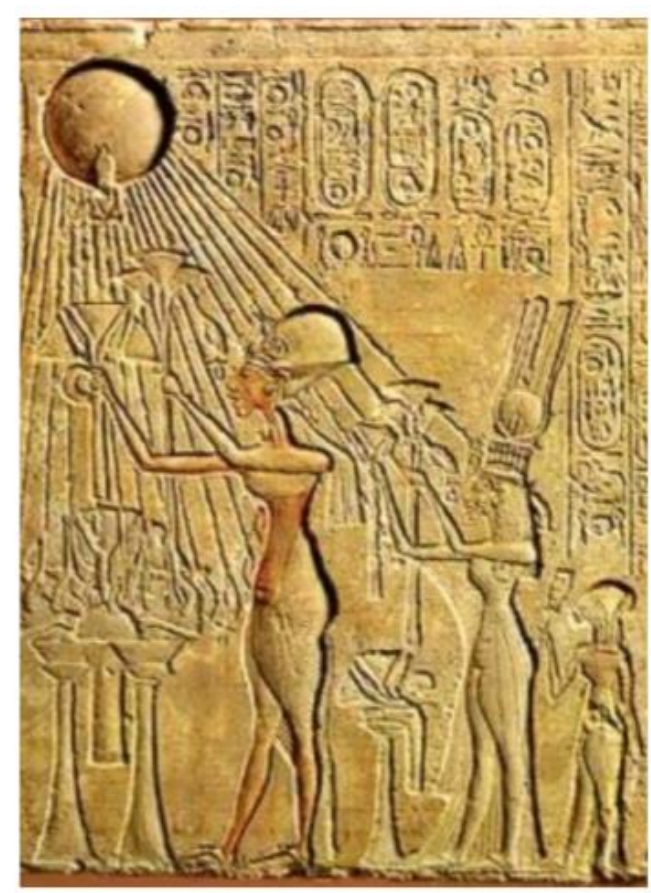

1. ábra. Aten, a napfény

Az ókori civilizációk megtanulták, milyen építési technikát kell alkalmazni, hogy a nap folyamán a nap energiáját eltárolják, hogy az este folyamán otthonaikat melegen tartsák. Tüzgyújtáshoz még üveget és tükröket is használtak.

Az első igazi napelemet Charles Fritts készítette New Yorkban: egy táblán szelén réteget vékony és félig átlátszó aranyfilmmel vont be 1885-ben, ami folyamatosan tudott áramot termelni. Fritts optimistán ki is jelentette, hogy - "egy napon még a fotovoltaikus áramtermelés versenyre kelhet a széntüzelésü elektromos erőmüvekkel" - amiből az elsőt egyébként Thomas Edison építette alig három évvel korábban. Az akkori kutatások és a felhasznált alapanyagok rendkívül drágák voltak, és ahogy fejlődni kezdett az energetikai ipar, egyre többen látták be, hogy az akkori napelem modulok sose hozzák be elöállítási költségüket az általuk termelt árammal. Ráadásul a szelén modulok gyorsan veszítettek is teljesítményükből [2].

Így az első próbálkozások után, majd a két világháború miatt egy időre háttérbe kerültek a napelemek és a fotovoltaikus kutatások és csak az 50-es években indultak igazán újra [4].

Az első elkészült napelem 0,5\%-os hatásfokú volt. Chapin fejlesztette ki az első tükröződést tompító megoldást: matt, de átlátszó müanyaggal vonva be a szilícium felületét, amivel már $4 \%$ közelébe került a hatásfok. Az 5-6\%-os cél még mindig messze volt. Bell 1954. április 25 -én mutatta be a nagyközönségnek napelemeit, kivívva a washingtoni Nemzeti Akadémia elismerését is. 

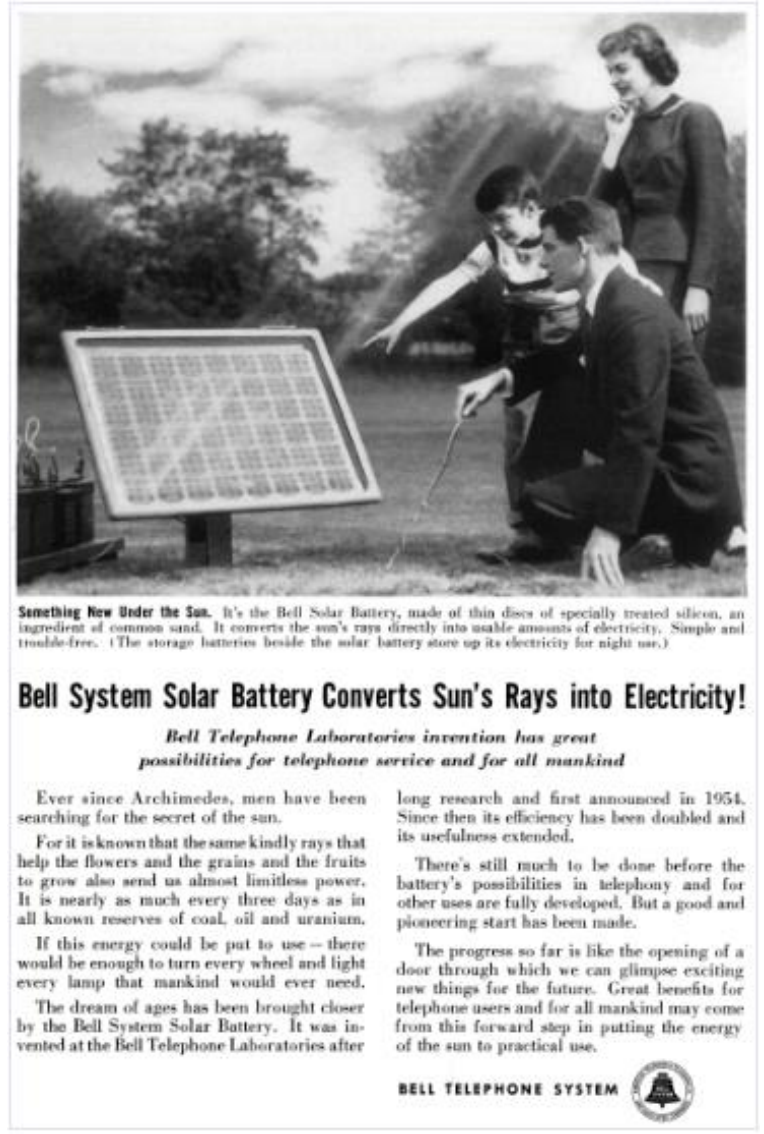

\section{2. ábra. New York Times cikke a napelemröl}

Ahogy azt a 2 ábrán is láthatjuk, a New York Times első oldalon számolt be az eredményről, és egy új korszak kezdetéről írtak, ami "elvezethet az emberiség egyik legfontosabb álmához, a Nap végtelen energiájának használatához a civilizáció szolgálatában". Ezzel kezdődött el a napelemek felhasználásának rögös útja [5].

\section{A napelem jelene (hogyan müködik a napelem)}

Egyszerủen fogalmazva: a napelem úgy múködik, hogy lehetővé teszi a fotonok vagy fényrészecskék atomoktól mentes elektronok gerjesztését, elektronáramlást generálva. A napelemek valójában sok kisebb elemet tartalmaznak, amelyeket fotoelektromos celláknak hívnak. A fotovoltaikus energia egyszerüen azt jelenti, hogy a napfényt elektromos árammá alakítja. Számos, egymással összekapcsolt elem alkotja a napelemet.

A működésükhöz a fotovoltaikus elemeknek elektromos mezőt kell létrehozniuk. Hasonlóan a mágneses mezőhöz, amely az ellenkező pólusok miatt lép fel, az elektromos mező akkor jön létre, amikor az ellenkező polaritású töltések elválasztódnak. Hogy ez megvalósuljon a gyártók szennyezik a szilíciumot más anyagokkal, így lesz minden szendvics-szelet pozitív vagy negatív elektromos töltésü [6]. 


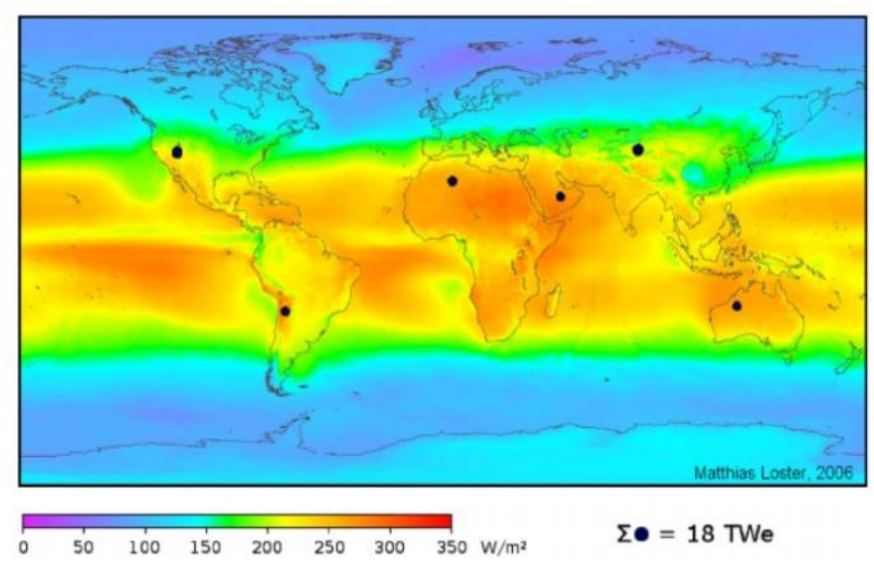

3. ábra. Hömérséklet eloszlás a Földön

Pontosabban, a foszfor-atommagot a szilícium felső rétegébe ágyazzák be, amely negatív töltés mellett további szabad elektronokat ad hozzá a réteghez. Eközben az alsó réteg egy adag bór szennyezést kap, ami kevesebb lyukat eredményez. Mindez elektron lyuk párokat hoz létre a szilícium rétegek között (p-n átmenet). Ezután, a napfény fotonja gerjeszti az elektront, melynek eredményeképpen az elektron kilép a pályájáról. Az így szabaddá vált elektronok elektromos áramot hoznak létre. A cella oldalán lévő fémvezető lemezek összegyüjtik az elektronokat, és azokat vezetékekre továbbítják. Ezen a ponton az elektronok úgy áramolhatnak, mint bármely más áramforrás esetén.

A közelmúltban a kutatók ultravékony, rugalmas napelemeket állítottak elö, amelyek vastagsága csak 1,3 mikron - az emberi hajszélesség kb. 1/100-a -, és 20-szor keskenyebb, mint egy irodai papír. Valójában a cellák annyira könnyüek, hogy akár egy szappanbuborék tetejére ültethetőek, és mégis ugyanolyan hatékonysággal termelnek energiát, mint a szilícium alapú napelemek - jelentették a tudósok egy, az Organic Electronics folyóiratban 2016-ban publikált tanulmányban. Az ilyen könnyebb, rugalmasabb napelemeket fel lehet használni az építőiparban, a repüléstechnikában vagy akár a hordozható elektronikában.

Vannak más típusú napenergia-technológiák is, amelyek másképp müködnek, mint a fotovoltaikus elemek, de ezek mindegyike kihasználja a napfény energiáját villamos energia előállításához vagy melegítéséhez [6].

Néhány definíció:

- $\quad$ Passzív napenergia: Ez nem foglalja magában mechanikai és elektromos eszközök használatát. Az ablakok, a falak és a padló télen hő formájában gyüjtik, tárolják és elosztják a napenergiát, nyáron pedig elviszik a napenergiát. Egyre több házat építenek az ilyen típusú napenergia felhasználására vagy eltérítésére

- Napkollektor: A napfény felhasználására szolgáló technológia. Az egyik felhasználás a víz melegítése kis vagy nagy mértékben.

- Koncentrált napenergia: Technológia napelemek elektromos áramának előállításához tükrök segítségével, a nagy mennyiségü napenergiát egy kis területre koncentrálva. Az elektromos energia akkor keletkezik, amikor a koncentrált fény hőre alakul át, amely egy villamos áramfejlesztőhöz csatlakoztatott hőtechnikai gép (általában gőzturbinát) hajt meg [2].

A 4. ábra egy un. szigetüzemü napelemes rendszert mutat be. 


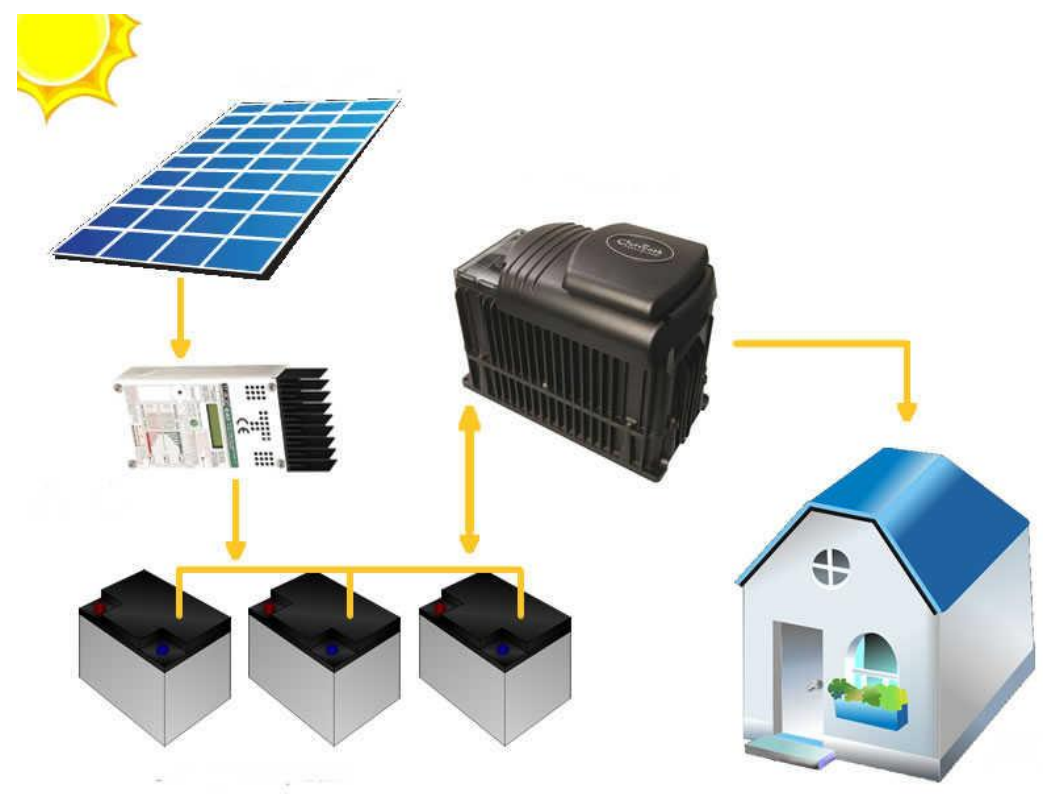

4. ábra. Szigetüzemü napelemes rendszer müködése

Kutatások folynak alternatív megoldásokra, melyekben melegvíz előállítására keresnek lehetőséget.

STCS (Solar Thermal Collector System)/ Napkollektoros rendszer tervezési folyamata

- Elsősorban a kutatók meghatározták, hogy mennyi hő szükséges a háztartási melegvíz előállításához egy 4 emberből álló család számára.

- A napkollektor mezőt, a csővezetékeket, a tárolótartályt, a tágulási tartályt és a szivattyút szintén megtervezték. A hőgyüjtők által termelt energia mennyiségét az év minden hónapjára kiszámították.

- Számításuk szerint 2 kollektorra van szükség ahhoz, hogy a használati melegvíz előállítása teljes mértékben napenergiából származhasson.

- A napkollektoros rendszerek nagy hatékonysága mellett a mechanizmusok gyakori karbantartása és kopása is előfordulhat.

- Az STCS tartalmaz egy 1,84 $\mathrm{m}^{2}$ abszorpciós felületü laposlemez-gyüjtőt, 300 l-es melegvíztároló tartályt, 18 1-es tágulási tartályt és $30 \mathrm{~m}$ hosszú hőszigetelt rézcsővezetéket.

PV-SWHS (Photovoltaic Solar Water Heater System) / Fotovoltaikus elemmel müködő vízfütő rendszer tervezési folyamata

- A rendszer napelemek alkalmazásával állítja elő a használati meleg vizet. A paneleket napelemes kábelek és vízmelegítő köti össze egy tároló víztartállyal. A PV-SWHS méretét ugyanarra a házra, négy före méretezték, mint a STCS-t.

- A PV-SWHS rendszer hat polikristályos napelemből áll, amik maximális teljesítménye $250 \mathrm{Wp}$ (Wattpeak), A rendszer része továbbá egy 80 literes hőtároló egység, egy $183 \mathrm{~V} / 1500$ W teljesítményü vízmelegítő és egy 30 m hosszúságú kábel.

- A fotovoltaikus rendszer még kevesebb beruházási, karbantartási és üzemeltetési költséggel jár, mint a kollektorrendszer, és szinte azonos jövedelmet generál. A fotovoltaikus rendszer megtérülési ideje ennek megfelelően rövidebb. 
Különböző számításokból és elemzésekből bebizonyosodott, hogy a fotovoltaikus rendszer kiküszöböli a napkollektoros rendszer számos hátrányát a melegvíz termelés szempontjából. Számítások rámutattak, hogy a PV-SHWS költséghatékonyabb, mint a napkollektoros rendszer [8].

1. táblázat. Fotovoltaikus és napkollektoros rendszer összehasonlitása

\begin{tabular}{|c|c|c|}
\hline Megnevezés & STCS & PV-SWHS \\
\hline $\begin{array}{c}\text { Termelt energia } \\
\text { [kWh/év] }\end{array}$ & 1547 & 1543 \\
\hline Felület [m²] & 1,84 & 9,56 \\
\hline $\begin{array}{c}\text { Beruházási költ- } \\
\text { ség [Ft] }\end{array}$ & 768100 & 523800 \\
\hline $\begin{array}{c}\text { Karbantartási } \\
\text { költség [Ft/év] }\end{array}$ & 11200 & 6700 \\
\hline $\begin{array}{c}\text { Müködtetési költ- } \\
\text { ség [Ft/év] }\end{array}$ & 9200 & 3900 \\
\hline $\begin{array}{c}\text { Bevétel [Ft/év] } \\
\text { Megtérülési idő } \\
\text { [év] }\end{array}$ & 65200 & 65000 \\
\hline
\end{tabular}

\section{Jövőkép: Perovszkit}

„A Perovszkit, avagy a napelem jövője”, ahogyan az euronews oldalán is említik [7]. Perovszkitek izgalmas, új típusú anyagok napelemek gyártásához, mert olcsó és nagy hatásfokú napelemeket lehet velük előállítani. Főbb előnyei a költségtakarékosság mellet a kiváló anyagminősége és fényelnyelő képessége [9]. A perovszkit nevü kristály ezerszer vékonyabb, mint a hagyományos szilícium, mégis többször bizonyította már, hogy hasonlóan hatékony. Néhány év alatt bizonyította, hogy hatékonysági mutatói ugyanúgy 22 százalékon állnak, mint a hagyományos szilíciumé. Mindez pedig azt jelentheti, hogy a jövőben a napenergia ára jelentősen csökkenhet.

A perovszkit félig átlátszó és rugalmas anyag. Az Európai Unió GOTSolar nevü projektjének részeként egy Lausanne-i politechnikumban végeznek napelemes kísérleteket.

„Ami meglepő a perovszkittel kapcsolatban, hogy egyszerü megoldásokkal és könnyen hozzáférhető anyagokból elóállítható, és olyan teljesítményt mutat, amely meghaladja a szilícium polikristályokét. Az egyetlen veszélyforrás az ólomtartalma, ami miatt nagyon óvatosan kell bánnunk vele. De ezt leszámítva, ez egy nagyon különleges anyag" - mondta Michael Grätzel, a Lausanne-i Politechnikum professzora.

Ahhoz, hogy az ólom esetleges káros hatásait kivédjék, a tudósok védöüveggel vonják be a napelemeket. Az utolsó réteg pedig aranyból készül, amely a két elektróda egyikeként müködik.

A GOTSolar projekt egyik szempontja az úgynevezett tandem technológia - a szilícium és a perovszkit együttes felhasználása.

A legérdekesebb az a tény, hogy kombinálni lehet ezt a technológiát azzal, amelyik szilíciumot használ, annak érdekében, hogy olyan cellákat kapjunk, amelyek hatékonysága eléri a 30 százalékot. Eindhovenben dolgoznak a kutatók a perovszkit napelemek fejlesztésén. Az Ö feladatuk az, hogy nagyobb skálán reprodukálják a laboratóriumi eredményeket, amely fontos lépés ahhoz, hogy ezek a napelemek kereskedelmi forgalomba kerülhessenek. Ennek a technológiának azonban néhány aspektusa még fejlesztés alatt áll, néhány olyan alapvető is, mint a stabilitás. Ha a legutolsó stabilitási, fejlesz- 
tési és technológiai eredmények megfelelőek lesznek, akkor a kutatók reményt látnak arra, hogy a hordozható technológia vagy a fogyasztói elektronika piacán hamar megjelenik a perovszkit, de olyan területeken, mint például az építőipari termékek piaca vagy az autóipar, ez valószínüleg később történik majd meg.

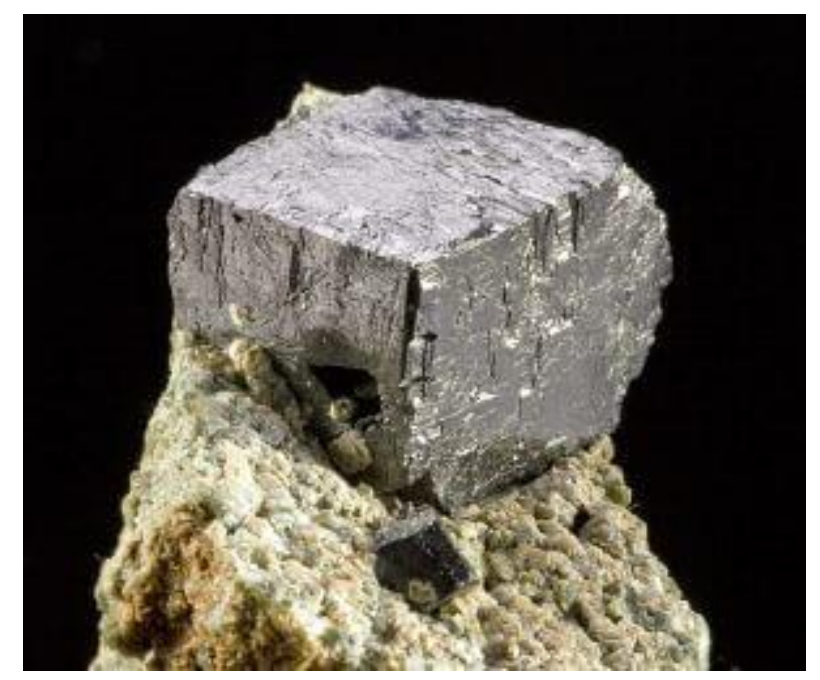

5. ábra. Perovszkit kristály

A napelemek jövőbeni felhasználási területe napról-napra bővül. A közlekedésben például a közutak és a repülöterek egyre növekvő villamos energia igényének - a forgalom irányítás közelmúltbani fejlődése miatt, mint például az intelligens szállítási rendszer (ITS) - a kielégítésére a közlekedési mérnökök különféle alternatívákat keresnek, amelyek kevesebb fosszilis tüzelöanyagot égetnek, és kevesebb széndioxidot bocsátanak ki. Az energiaigény csökkentése érdekében a legjelentősebb megközelítés a napenergia begyüjtése a szállítási infrastruktúrákból. New Jersey államban például az autópálya mentén a legtöbb elektromos jelzőtáblát merev napelemekkel látták el [10]. További hasonló, közlekedéshez kapcsolódó alkalmazásról írnak a szerzői abban az áttekintő és összefoglaló cikkben, amiben példaképpen említik azt a Hollandiában található kerékpárút, ahol LED-eket tartalmazó panelek biztosítják a vonalakat és a különböző burkolati jeleket, anélkül, hogy azokat felfestenék, így nagyobb változtatási szabadságot biztosít. Jelezni tudja, ha állat halad át elöttünk az úton. Melegítő elemeket is tartalmaz, így a jegesedés veszélye elkerülhető. A panelekbe mikrochippeket is építettek, így azok kommunikálnak egymással, az irányító központtal, valamint a jármüvekkel. Kínában is folynak kísérletek, ahol az autóutba épített a paneleket egy vékony betonréteggel fedték le, hogy védjék az autók terhelésétől. A paneleket úgy képezték ki, hogy azok képesek az energiát átadni a rajtuk hajtó elektromos jármüveknek illetve azonnal megolvasztják a rájuk eső havat. Hátránya, hogy alacsony a teherbírása, csak személyautók terhelhetik, teherautó és kamionokat már nem bír el [11]. A napelemek használata az autógyártásban is megjelenik. A napelemeket az autók karosszériájára, tetőre vagy a motorháztetőre rögzítik filmrétegként. Itt fejlesztési szempont a hatásfok növelése - a Toyota új rendszere eléri a 34\%-t - valamint az energiatárolási rendszer javítása [12]. 


\section{5. Összefoglalás}

A megújuló energia felhasználásának számos potenciális előnye van, ideértve az üvegházhatású gázok kibocsátásának csökkentését, az energiaellátás diverzifikációját és a fosszilis tüzelőanyagok (különösen az olaj és a gáz) piacaitól való függőség csökkentését. A megújuló energiaforrások növekedése potenciálisan ösztönözheti a foglalkoztatást az EU-ban azáltal, hogy munkahelyeket teremt az új „zöld" technológiákban.

A közvetlenül a napsugárzásból villamos energiát előállító napelemeket széles körben használják lakóépületekben. Ezek müködési elve meglehetősen egyszerü, és nincs szükség drága és összetett segédberendezésekre. A napkollektorok mellett más irányzatokban is zajlanak fejlesztések, mint például a fotovoltaikus napos vízfütő rendszer megalakítása, mellyel a napkollektorok számos hátrányát lehetne kiküszöbölni a melegvíz termelés szempontjából, illetve fotovoltaikus rendszer költséghatékonyabb, mint a napkollektoros.

A napelemek jövőjében megjelenik egy új anyag, a perovszkit, mely egy új szintre emelheti a napelemek továbbfejlesztését.

\section{Irodalom}

[1] https://www.researchgate.net/publication/318410023_The_history_of_using_solar_energy (2019.10.20.)

[2] https://www.greenmountainenergy.com/2014/06/solar-energy-past-present-future/ (2019.10.20)

[3] https://napelemek.blog.hu/2009/11/28/napelem_tortenelem_1_resz (2019.11.02.)

[4] https://napelemek.blog.hu/2010/01/23/napelem_tortenelem_2_resz (2019.11.02.)

[5] https://www.livescience.com/41995-how-do-solar-panels-work.html (2019.11.02.)

[6] https://hu.euronews.com/2018/02/26/perovszkit-avagy-a-napelem-jovoje (2019.11.07.)

[7] Boldizsár, Cs., Bodnár, I., Szaszák, N., Koós, D.: Designing producere of innovative photovoltaic solar water heater system, Acta Technika Corviniensis - Bulletin of Engineering, 2016., ISSN:2067-3809

[8] https://arena.gov.au/assets/2018/01/development-of-stable-electrodes-for-perovskite-solarcells.pdf (2019.11.07.)

[9] Bodnár, I.: Napelem müködésének alapjai, a napelemes villamosenergia-termelés elmélete és gyakorlati megvalósítása, Micropress Kft., Miskolc, 2019., ISBN 978-615-00-4566-5

[10] Wayne Lee, K., Correia, A.J., Neilan, B.D.J., Dahn, B.: Comparative Study of Solar Panels for Roadway Operations, Advanced Materials Research (Volume 723), 2013; pp 594-600 https://doi.org/10.4028/www.scientific.net/AMR.723.594

[11] Papadimitriou, C.N., Psomopoulos, C.S., Kehagia, F.: A review on the latest trend of Solar Pavements in Urban Environment, Energy Procedia, Volume 157, January 2019, Pages 945952 https://doi.org/10.1016/j.egypro.2018.11.261

[12] Bencs, P., Voith, K.: (2020) Napelemekben rejlö lehetőségek. Műszaki Magazin, 30 (1-2). pp. 58-62. ISSN 1417-0132 